УДК 004.94

${ }^{[0000-0002-6204-0708]}$ T. О. Прокопенко, д.m.н., професор,

завідувач кафедри інформачійних технологій проектування

e-mail: t.prokopenko@chdtu.edu.ua

[0000-0001-5571-2281] О. В. Лавданська, к.m.н.,

доцент кафедри інформаційних технологій проектування

e-mail: yegorovaov@gmail.com

Черкаський державний технологічний університет

б-р Шевченка, 460, м. Черкаси, 18006, Україна

\title{
ОЦНКА КОНФЛІКТНОСТІ КОМПОЗИЦІЇ РОЛЕЙ ПРОДУКТОВОГО МЕНЕДЖЕРА І ВЛАСНИКА ПРОДУКТУ У ПРОЕКТНИХ КОМАНДАХ
}

У статті порівнюються функиіональні обов'язки продуктового менеджера і власника продукту. Наведено підходи до структуризаиії команд розробників програмного забезпечення. Розглянуто обов'язки та завдання менеджера продукту і власника продукту. 3 'ясовано, що менеджер продукту як член проектної команди відповідає за прийняття бізнес-рішень та розробку стратегії продукту, а власник продукту відповідає за створення иінності IT-продукту. Діяльність продуктового менеджера орієнтована на стратегічний розвиток IT-продукту, а власника продукту - на досягнення тактичних иілей під час створення $і$ вдосконалення IT-продукту. Частково сфери відповідальності продуктового менеджера і власника продукту перетинаються. Делегування виконання одній людині ролі продуктового менеджера і власника продукту може призвести до втрати стратегічного бачення иілей IT-продукту або ж надмірного заглиблення у прочес розробки програмного забезпечення.

Ключові слова: agile, Scrum, методологія, продукт, менеджер, власник, обов'язки, навички.

Вступ. Поява лаконічного і змістовного документа у вигляді Agile-маніфесту [1] спричинила справжню революцію у сфері розробки програмного забезпечення. Відтоді ITкомпанії по всьому світу по-різному сприйняли, адаптували свою структуру і розробляють програмне забезпечення на основі таких гнучких методологій розробки, як Scrum, Kanban, Extreme Programming, Crystal, Dynamic System Development Method, Feature-Driven Development чи Lean Development. Дедалі частіше 3'являються успішні приклади використання гнучких методологій для реалізації телекомунікаційних, рекламних, фінансових, промислових та інших проектів.

Розробка програмного продукту є творчим процесом, який потребує наявності всередині компанії нових ідей, спеціального фонду для їх реалізації і талановитих працівників. Результатом такої розробки має бути унікальний продукт, який би задовольняв потреби користувачів та бажання замовника, а також гідна винагорода для всіх учасників процесу розробки за свою діяльність.
Реалізація проектів інформатизації в кожній галузі відбувається із залученням широкого кола фахівців різних спеціальностей та 3 використанням диференційованих підходів для врахування специфічних особливостей галузі, проте основні аспекти процесу розробки програмного забезпечення залишаються незмінними.

Ключові принципи гнучких методологій, що дотичні до команди проекту, декларують [2]:

- щоденну співпрацю розробників і представників бізнесу впродовж реалізації усього проекту;

- залучення для роботи над проектом вмотивованих професіоналів, для яких створено належні умови праці та яким надано необхідну підтримку;

- підтримку особистої комунікації як найбільш ефективного i практичного методу донесення інформації до команди та її поширення всередині команди;

- розподіл обов'язків та відповідальності у проекті шляхом використання рольової моделі. 
В умовах зменшення часової відстані між виникненням ідеї програмного продукту та виведенням його на ринок здатність команд використовувати колективну мудрість усієї команди для оптимальної організації роботи стала вирішальною в усіх гнучких методологіях. Яким чином сучасні команди розробників програмного забезпечення структурують свою роботу, які ролі і обов'язки має кожний член команди і як з'ясувати, наскільки ефективно працює команда із продуктом?

Метою дослідження $\epsilon$ аналіз та порівняння функціональних обов'язків менеджера продукту i власника продукту у Scrumкомандах для вивчення необхідності запровадження цих ролей у проекті, можливості їх виконання однією людиною та впливу поєднання ролей на ефективність виробництва якісного програмного продукту.

Задачами дослідження є:

- аналіз підходів до структуризації команд розробників програмного забезпечення;

- аналіз обов'язків та навичок менеджера продукту;

- аналіз обов'язків та навичок власника продукту.

\section{Виклад основного матеріалу}

1. Підходи до структуризації команд розробників програмного забезпечення. Як зазначають дослідники в $[3,4]$, в гнучких методиках розробки програмного забезпечення утворення команди базується на принципах самоорганізації. Щоб зрозуміти та реалізувати концепцію самоорганізації, командам необхідний деякий час, але наявність необхідного програмного забезпечення для управління проектами, навчання, менторство та керівництво, безумовно, забезпечують здатність самоорганізованих команд швидко створити якісний продукт в динамічних умовах [5].

В одному 3 підходів до структуризації команди розробників програмного забезпечення, що описаний в роботі [6], гнучкі команди розробників програмного забезпечення поділяють на три типи: «команда пілотів», яка займається управлінням проектом; «комп'ютерна команда», яка займається створенням нових програмних продуктів; «команда клубу веселих та кмітливих», яка займається розв'язанням складних проблем.
У другому підході $[7,8]$ команди розробників програмного забезпечення поділяють на універсальні, спеціалізовані та гібридні. Універсальна команда відповідає за забезпечення неперервності роботи над проектом. Вона складається 3 фахівців, які володіють різнопрофільними навичками та досвідом. До складу спеціалізованих команд запрошують фахівців, які володіють спеціальними знаннями та навичками у певній предметній області. Водночас кожен із них відповідає за реалізацію відповідної складової частини проекту. Гібридні команди формуються на основі універсальних та вузькоспеціалізованих фахівців, які вже працюють над поточним проектом, але у разі потреби можуть скоротити перелік призначених для них задач.

Автори іншого підходу у праці [9] виділяють команди розробників програмного забезпечення таких типів: «команда для виконання потоку робіт», яка призначена для створення та постачання цінностей замовнику чи користувачу швидко, безпечно і незалежно від інших команд, що працюють над проектом; «команда для розробки складних підсистем», що відповідає за розробку та підтримку тієї частини програмної системи, яка настільки сильно залежить від знань спеціалістів, що більшість членів команди повинні бути фахівцями в цій галузі знань, щоб зрозуміти та внести зміни в підсистему; «команда-платформа», яка призначена для надання основних внутрішніх послуг командам, що вирівнюють потоки, або для надання функціональних можливостей вищого рівня 3 метою зменшення когнітивного навантаження.

Незалежно від обраної IT-компанією структури команди розробників, кожному представникові команди розробників делегується виконання певної ролі у проекті. В сучасних IT-проектах використовують щонайменше шість ролей із перелічених $[10,11]$ : менеджер продукту (product manager), менеджер проекту (project manager), UI/UXдизайнер (UI/UX designer), команда розробників (development team), команда із забезпечення якості (QA team), системний архітектор (software architect), бізнес-аналітик (business analyst), делівері-менеджер (delivery manager).

Як відомо, Scrum-команда розробників програмного забезпечення складається із Scrum-майстра (Scrum master), власника про- 
дукту (product owner) і команди розробників (developers).

Чи може одна людина у проекті поєднувати виконання проектної ролі і ролі у Scrumкоманді? Скільки проектних i Scrum-ролей може виконувати одна людина? Які проектні i Scrum-ролі може виконувати одна людина? Відповіді на ці запитання є інтуїтивно зрозумілими щодо команди розробників. Найбільше ж протиріч виникає щодо проектної ролі менеджера продукту (product manager) i Scrum-ролі власника продукту (product owner). Згідно з цілями дослідження з'ясуємо, якими мають бути менеджер продукту і власник продукту, розглянемо функціональні обов'язки, які вони виконують, та визначимо необхідні для цього знання.

2. Обов'язки та навички менеджера продукту. Продуктовий менеджер - це фахівець у сфері інформаційних технологій, бізнесу та досвіду взаємодії користувача із продуктом, діяльність якого спрямована на концептуальну розробку, забезпечення та утримання успішності IT-продукту на ринку.

Обов'язки менеджера продукту суттєво різняться на різних етапах розвитку продукту. Фредерік Е. Вебстер (Frederick Е. Webster, Jr.) виділяє сім етапів розробки нового продукту [12]:

- розробка стратегії нового продукту;

- генерація ідеї нового продукту;

- формування первинної множини ідей;

- бізнес-аналіз;

- безпосередня розробка продукту;

- тестування продукту на ринку;

- монетизація продукту.

Класифікацію продуктових менеджерів за новизною версій програмних продуктів, над якими вони працюють, наведено в [13], де виділяють:

- продуктового менеджера, який працює над поточною версією продукту і відповідає за ії зростання;

- продуктового менеджера, який займається плануванням і розробкою наступного випуску продукту;

- продуктового менеджера, який працює над майбутніми продуктами і ринками, визначає стратегію продукту.

Управлінська команда відомого онлайнмайданчика для розміщення та пошуку короткострокової оренди приватного житла по всьому світу «Airbnb» залучає для роботи у компанії продуктових менеджерів із принципово різним набором навичок та вмінь i, залежно від етапу розвитку продукту, умовно поділяє їх на три категорії [14]:

- «відкривачі» (pioneers) залучаються до роботи над продуктом на етапі розробки його ідеї;

- «поселенці» (settlers) залучаються до роботи над продуктом на етапі його зростання;

- «містобудівники» (town planners) залучаються до роботи над вже розвиненими продуктами.

В [15] продуктових менеджерів класифікують за ознакою причетності до певного етапу розвитку стартапу:

- продуктовий менеджер, який працює над стартапом;

- продуктовий менеджер, який працює над діючим продуктом;

- продуктовий менеджер, який працює в стартапі, що «зміг втриматися на плаву»;

- продуктовий менеджер, який працює в «кишеньковому» стартапі;

- $\quad$ продуктовий менеджер, який працює над продуктом, що успішно розвивається.

Продуктового менеджера часто порівнюють із архітектором, який проектує будинки, чи дизайнером одягу або ж сценаристом художнього фільму, які вміють сформувати концепцію продукту та пропонують іi реалізувати команді розробників. Продуктовий менеджер шукає на ринку проблеми, які може вирішити компанія, досліджує конкурентне середовище та цільову аудиторію, а потім працює 3 командами розробників і маркетологів, для того щоб вивести сформовані рішення на ринок. Продуктовий менеджер концентрує зусилля на розвитку продукту, який із мінімальними інвестиціями принесе найбільший прибуток. Продуктовий менеджер відповідає за бачення і напрям розвитку продукту у довгостроковій стратегії компанії.

До обов'язків менеджера продукту належать [16-19]:

- визначення ринкових потреб та очікувань клієнтів, взаємодія із замовниками та ринками;

- аналіз конкурентного середовища, розуміння сильних і слабких сторін конкурентів, тенденцій ринку; 
- розробка та управління ідеями, що забезпечать цінність для споживачів;

- оцінювання привабливості бізнесможливостей;

- управління баченням, цілями та дорожньою мапою продукту;

- управління релізами шляхом визначення пріоритетності важливих для користувачів функцій;

- формування, збір і аналіз вимог до продукту через спілкування із замовником та його командою;

- визначення та аналіз ключових метрик продукту;

- покращення досвіду використання продукту;
- краудсорсинг, тестування ідеї або прототипу майбутнього продукту на потенційних споживачах;

- надання підтримки команді у постачанні рішень.

Загалом продуктовий менеджер повинен:

- бути корисним для споживачів;

- приносити максимальну цінність компанії та відповідати їі баченню;

- швидко генерувати i впроваджувати ідеї, які принесуть компанії гроші;

- правильно визначати ціну товару;

- приймати ризики і керувати ними;

- професійно комунікувати й аналізувати поведінку людей.

Компетентності продуктового менеджера наведено на рисунку 1.

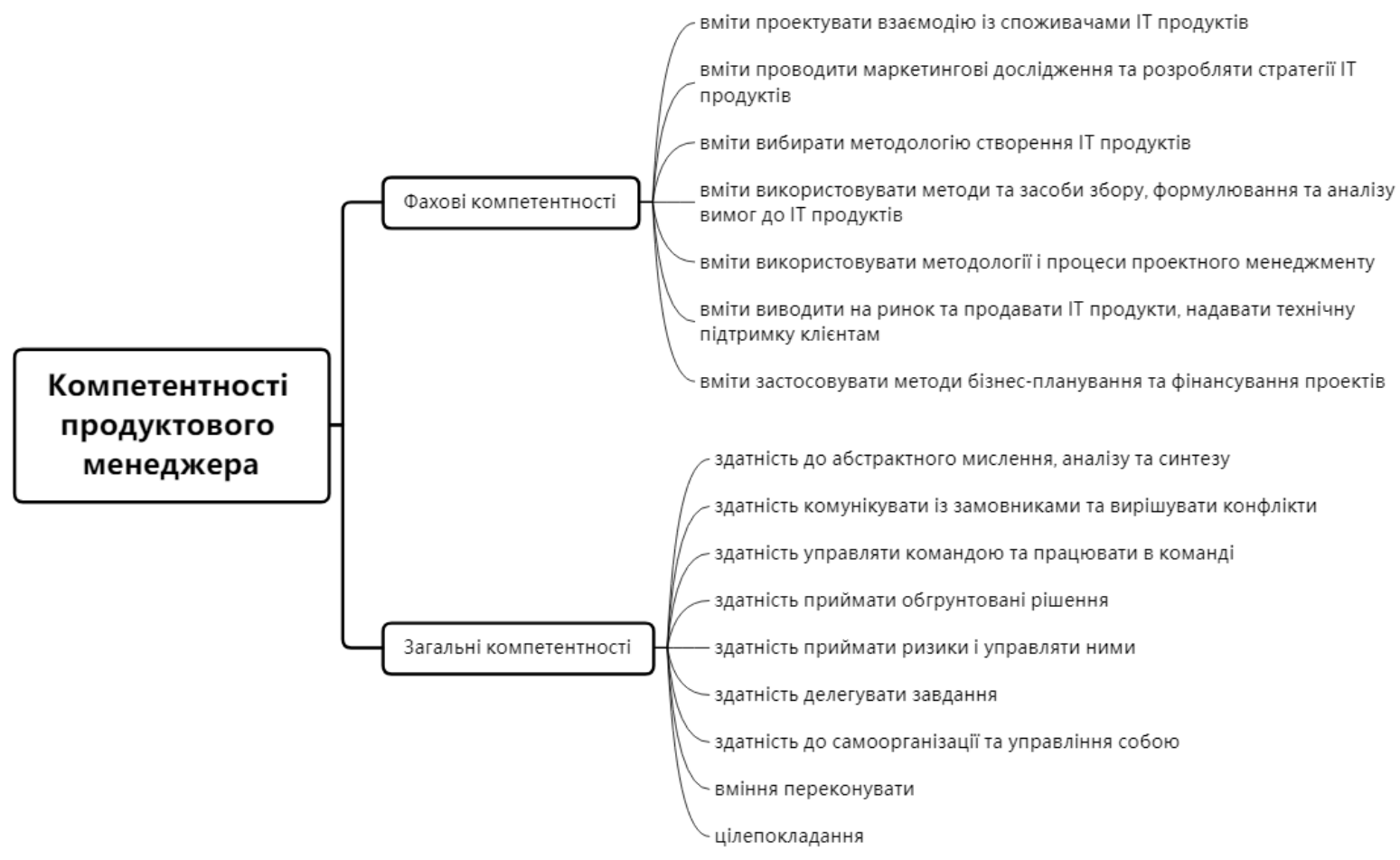

Рисунок 1 - Компетентності продуктового менеджера

Джерело: власне опрацюювання на підставі [18], [20], [21]

Отже, менеджер продукту - це член проектної команди, який відповідає за прийняття бізнес-рішень та розробку стратегії продукту, що принесе дохід завдяки вирішенню проблеми користувачів.

3. Обов'язки та навички власника продукту. Власник продукту - це роль у Scrum-команді, виконавцю якої делегується відповідальність за управління проектом або набором проектів для створення і вдосконалення IT-продукту.

Діяльність власника продукту спрямована на отримання працездатного IT-продукту, який відповідає очікуванням користувачів, а також створює цінність для зацікавлених сторін, що мають до нього доступ. Власник продукту керує backlog, визначає пріоритети задач у backlog, формує користувацькі історії, 
взаємодіє 3 продуктовим менеджером, командою проекту та користувачами продукту, а іноді навіть контролює бюджет на розробку продукту.

До обов'язків власника продукту належать [18, 19, 22, 23]:

- взаємодія з командою розробників і технологіями;

- участь у формуванні командних рішень;

- створення списку задач, які необхідно виконати;

- наповнення та реалізація backlog;

- планування ітерацій і створення користувацьких історій;

- встановлення пріоритетів для користувацьких історій;

- визначення критеріїв приймання реалізації користувацьких історій;

- визначення шляхів підвищення цінності продукту;
- участь у процесі прийому нових учасників до проектної команди.

Власник продукту повинен:

фреймворки;

- бути корисним для команди розробників;

- контролювати ключові проблеми та створення цінності IT-продукту;

- виконувати декомпозицію проекту на окремі задачі та встановлювати їх пріоритетність;

- прогнозувати тренди майбутнього на основі доступних даних;

- працювати над оптимізацією IT-продукту;

- складати технічну документацію;

- володіти організаційними, аналітичними та комунікативними навичками.

Компетентності власника продукту наведено на рисунку 2.

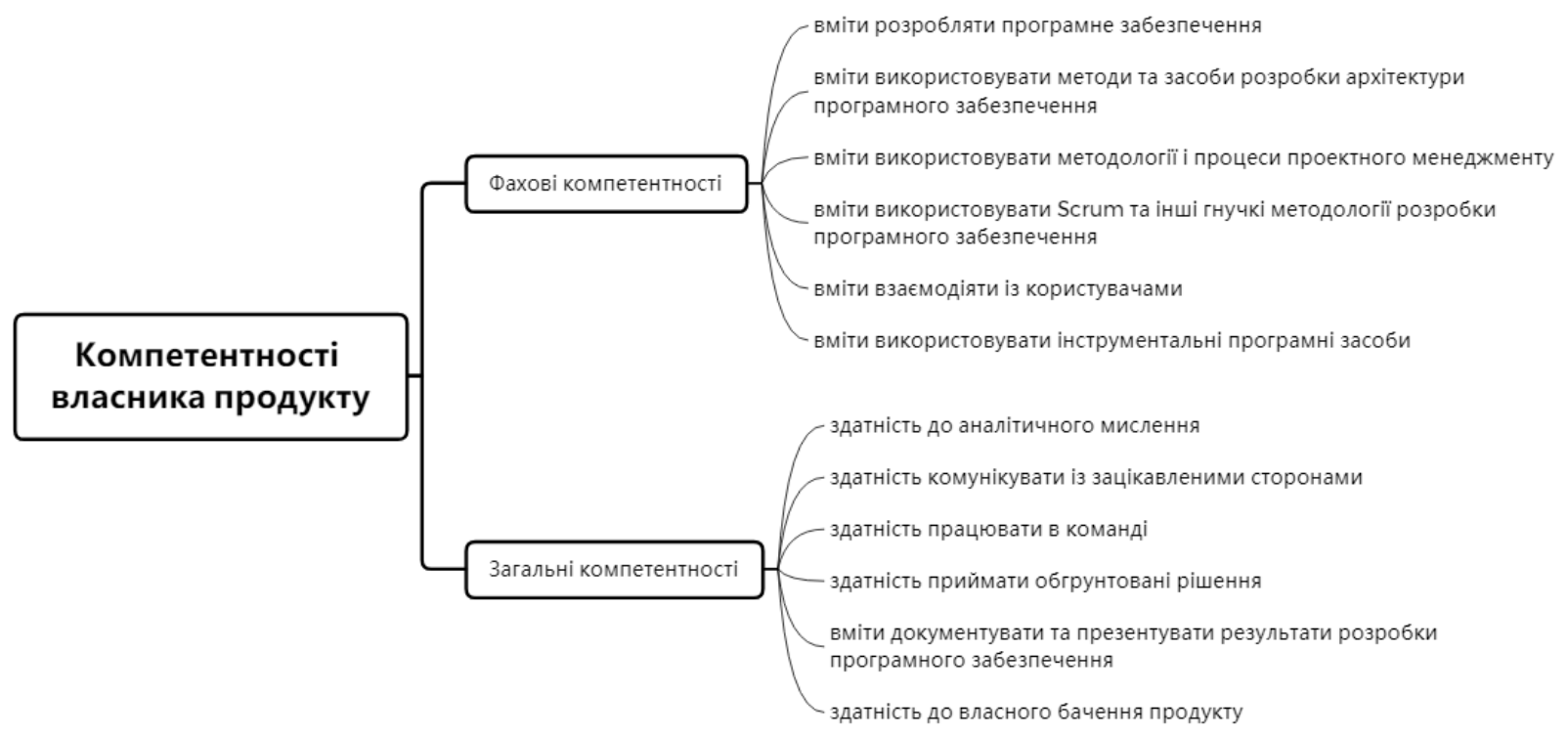

Рисунок 2 - Компетентності власника продукту

Джерело: власне опрацювання на підставі [23], [24], [25]

Отже, власник продукту - це роль у Scrum-команді, виконавець якої створює цінність IT-продукту, розробляє дорожню карту продукту i список задач у проекті, а також представляє продукт перед розробниками та іншими стейкхолдерами.

Результати досліджень функціональних обов'язків та компетентностей продуктового менеджера і власника продукту свідчать (C) Т. О. Прокопенко, О. В. Лавданська, 2021 DOI: $10.24025 / 2306-4412.1 .2021 .231582$ про наявність принципових відмінностей між цими ролями. Продуктовий менеджер не прив'язаний до жодної методології чи фреймворку, а власник продукту належить до Scram-методології.

Продуктовий менеджер відповідає за формування бачення i визначення напрямів розвитку IT-продукту. Він досліджує конкурентне середовище та цільову аудиторію, 
а потім працює 3 командами розробників і маркетологів для того, щоб вивести сформовані рішення на ринок.

Власник продукту відповідає за створення цінності IT-продукту. Він керує backlog та взаємодіє $з$ продуктовим менеджером, командою проекту i користувачами продукту завдяки наявності здатності розробляти, супроводжувати та забезпечувати якість програмного забезпечення.

Обговорення. На теоретичному рівні виконання однією людиною ролей продуктового менеджера і власника продукту видається реально можливим. Така ситуація є прийнятною для стартапів, які ще не встигли накопичити досвід. На практиці ж об'єднання ролей спричиняє необхідність балансування стратегічних і тактичних цілей, а також виведення деяких функціональних обов'язків за межі сфери відповідальності. Це призводить до втрати стратегічного бачення цілей IT-продукту або ж надмірного заглиблення у процес розробки програмного забезпечення, що негативно позначається на цінності IT-продукту та його якості. Безперечно, частково сфери відповідальності продуктового менеджера і власника продукту перетинаються, що зумовлює необхідність співпраці та колективного прийняття рішень.

Висновки. Виконаний порівняльний аналіз функціональних обов'язків менеджера продукту i власника продукту у проектних командах дав можливість встановити, що продуктовий менеджер загалом відповідає за розробку концепції ІT-продукту, позиціонування його на ринку та формування планів і напрямів розвитку, а власник продукту відповідає за реалізацію плану виробництва IT-продукту з урахуванням наявних часових, вартісних та якісних обмежень. Делегування виконання одній людині ролі продуктового менеджера і власника продукту можливе протягом кількох місяців, але в перспективі це призведе до погіршення якості ІТ-продукту.

У контексті проведеного аналізу подальшого дослідження потребують питання вимірювання впливу компетентності менеджера продукту i власника продукту на якість IT-продукту 3 урахуванням спеціалізації IT-компанії та питання розвитку професійної майстерності обох ролей.

(C) Т. О. Прокопенко, О. В. Лавданська, 2021 DOI: $10.24025 / 2306-4412.1 .2021 .231582$

\section{Список використаних джерел}

[1] M. Fowler, and J. Highsmith, "The agile manifesto", Software Development Magazine, vol. 9, no. 8, pp. 28-35, 2001.

[2] "Основні принципи Agile-маніфесту". [Електронний ресурс]. Режим доступу: https://agilemanifesto.org/iso/uk/principles. html.

[3] R. Hoda, and L. K. Murugesan, "Multi-level agile project management challenges: A self-organizing team perspective", Journal of Systems and Software, vol. 117, pp. 245257, 2016.

[4] N. B. Moe, T. Dingsøyr, and T. Dybå, "Understanding self-organizing teams in agile software development", in Proc. 19th Australian Conf. on Software Engineering 2008 (ASWEC 2008), 2008, pp. 76-85.

[5] "Why do you need self-organizing teams in an agile environment?" [Online]. Available: https://kissflow.com/project/agile/importance -of-self-organizing-teams/.

[6] N. B. Moe, T. Dingsøyr, and T. Dybå, "Overcoming barriers to self-management in software teams", IEEE software, vol. 26, no. 6, 2009.

[7] "Как выглядит структура команды Agile разработки?" [Электронный ресурс]. Режим доступа: https://itanddigital.ru/ agileteam?

[8] K. Mangu-Ward, "Three types of agile teams". [Online]. Available: https://www.aug.co/blog/three-types-ofagile-teams

[9] M. Skelton, and P. Manuel, Team Topologies. IT Revolution Press, 2019.

[10] "6 ключевых ролей в команде разработки программного обеспечения". [Электронный ресурс]. Режим доступа: https://smartum.pro/ru/blog-ru/6-roley-vkomande-razrabotki-programmnogoobespecheniya/.

[11] M. Andrew, "Software development roles and responsibilities in outsourcing". [Online]. Available: https://qarea.com/ blog/software-development-roles-andresponsibilities-in-outsourcing.

[12] F. E. Webster Jr., Industrial Marketing Strategy, $3^{\text {rd }}$ ed. Wiley, 2008. 
[13] Курс Product Manager. Управление продуктом. Продакт. [Электронный pecypc]. Режим доступа: https://analytics.infozone.pro/free-trainingcourse-product-manager/.

[14] Airbnb Product Manager (PM) Interview Guide. [Online]. Available: https://www.tryexponent.com/guides/airbnb/ $\mathrm{pm}$-interview/tips-on-case-studypresentation.

[15] A. Karol, и М. Ротарь, "Роль Product Manager на разных этапах развития проекта". [Электронный ресурс]. Режим доступа: https://dou.ua/lenta/articles/productmanager-roles/.

[16] "What is the role of a product manager?" [Online]. Available: https://www.aha.io/ roadmapping/guide/productmanagement/what-is-the-role-of-a-productmanager.

[17] V. Mirnenko, "Ні батога, ні пряника: чим і як керує product manager". [Електронний pecypc]. Режим доступу: https://dou.ua/lenta/articles/productmanager/.

[18] М. Мельник, "Product owner vs product manager или product owner/product manager". [Электронный ресурс]. Режим доступа: https://skillsup.ua/blog/2021/01/it-roleproduct-owner/.

[19] "Product manager vs. product owner". [Online]. Available: https://www.productplan.com/learn/productmanager-vs-product-owner/.

[20] "Top skills for a product manager: A comprehensive list". [Online]. Available: https://www.indeed.com/career-advice/ resumes-cover-letters/skills-for-productmanager.

[21] A. Doyle, "Important skills for product manager jobs". [Online]. Available: https://www.thebalancecareers.com/list-ofproduct-manager-skills-2062460.

[22] "7 key product owner responsibilities". [Online]. Available: https://www.lucidchart.com/ blog/productowner-roles-and-responsibilities.

[23] "Product owner role в Скраме: обязанности, масштаб". [Электронный ресурс]. Режим доступа: https://brainrain.com.ua/ product-owner/.

(C) Т. О. Прокопенко, О. В. Лавданська, 2021

DOI: $10.24025 / 2306-4412.1 .2021 .231582$
[24] J. Fechter, "Essential product owner skills in 2021". [Online]. Available: https://productmanagerhq.com/productowner-skills/.

[25] D. Pereira, "What are the skills that a product owner must have". [Online]. Available: https://uxdesign.cc/what-are-the-skills-thata-product-owner-must-have-5bf033a153dc.

\section{References}

[1] M. Fowler, and J. Highsmith, "The agile manifesto", Software Development Magazine, vol. 9, no. 8, pp. 28-35, 2001.

[2] "Basic principles of the Agile Manifesto". [Online]. Available: https://agilemanifesto.org/iso/uk/principles. html [in Ukrainian].

[3] R. Hoda, and L. K. Murugesan, "Multi-level agile project management challenges: A self-organizing team perspective", Journal of Systems and Software, vol. 117, pp. 245257, 2016.

[4] N. B. Moe, T. Dingsøyr, and T. Dybå, "Understanding self-organizing teams in agile software development", in Proc. 19th Australian Conf. on Software Engineering 2008 (ASWEC 2008), 2008, pp. 76-85.

[5] "Why do you need self-organizing teams in an agile environment?" [Online]. Available: https://kissflow.com/project/agile/importance -of-self-organizing-teams/.

[6] N. B. Moe, T. Dingsøyr, and T. Dybå, "Overcoming barriers to self-management in software teams", IEEE software, vol. 26, no. 6, 2009.

[7] "How does the structure of an Agile development team look like?" [Online]. Available: https://itanddigital.ru/agileteam? [in Russian].

[8] K. Mangu-Ward, "Three types of agile teams". [Online]. Available: https://www.aug.co/blog/three-types-ofagile-teams.

[9] M. Skelton, and P. Manuel, Team Topologies. IT Revolution Press, 2019.

[10] "6 key roles in a software development team". [Online]. Available: https://smartum.pro/ru/blog-ru/6-roley-vkomande-razrabotki-programmnogoobespecheniya/ [in Russian]. 
[11] M. Andrew， "Software development roles and responsibilities in outsourcing". [Online]. Available: https://qarea.com/ blog/software-development-roles-andresponsibilities-in-outsourcing.

[12] F. E. Webster Jr., Industrial Marketing Strategy, $3^{\text {rd }}$ ed. Wiley, 2008.

[13] Course Product Manager. Product management. Product. [Online]. Available: https://analytics.infozone.pro/free-trainingcourse-product-manager/ [in Russian].

[14] Airbnb Product Manager (PM) Interview Guide. [Online]. Available: https://www.tryexponent.com/guides/airbnb/ pm-interview/tips-on-case-studypresentation.

[15] A. Karol, and M. Rotar, "The role of the product manager at different stages of project development". [Online]. Available: https://dou.ua/lenta/articles/productmanager-roles/ [in Russian].

[16] "What is the role of a product manager?" [Online]. Available: https://www.aha.io/ roadmapping/guide/productmanagement/what-is-the-role-of-a-productmanager.

[17] V. Mirnenko, "No whip, no gingerbread: what and how the product manager manages". [Online]. Available: https://dou.ua/lenta/articles/productmanager/ [in Ukrainian].
[18] M. Melnyk, "Product owner vs product manager or product owner/product manager". [Online]. Available: https://skillsup.ua/blog/2021/01/it-roleproduct-owner/ [in Russian].

[19] "Product manager vs. product owner". [Online]. Available: https://www.productplan.com/learn/productmanager-vs-product-owner/.

[20] "Top skills for a product manager: A comprehensive list". [Online]. Available: https://www.indeed.com/career-advice/ resumes-cover-letters/skills-for-productmanager.

[21] A. Doyle, "Important skills for product manager jobs". [Online]. Available: https://www.thebalancecareers.com/list-ofproduct-manager-skills-2062460.

[22] "7 key product owner responsibilities". [Online]. Available: https://www.lucidchart.com/ blog/productowner-roles-and-responsibilities.

[23] "Product owner role in Scrum: responsibilities, scope". [Online]. Available: https://brainrain.com.ua/ product-owner/.

[24] J. Fechter, "Essential product owner skills in 2021". [Online]. Available: https://productmanagerhq.com/productowner-skills/.

[25] D. Pereira, "What are the skills that a product owner must have". [Online]. Available: https://uxdesign.cc/what-are-the-skills-thata-product-owner-must-have-5bf033a153dc.

T. O. Prokopenko, D.Tech.Sc., professor, head of the department of information technology design, e-mail: t.prokopenko@chdtu.edu.ua

O. V. Lavdanska, Ph.D., associate professor of the department of information technology design e-mail: yegorovaov@gmail.com

Cherkasy State Technological University Shevchenko blvd, 460, Cherkasy, 18006, Ukraine

\section{ASSESSMENT OF THE CONFLICT COMPOSITION OF THE ROLES OF PRODUCT MANAGER AND PRODUCT OWNER IN PROJECT TEAMS}

The article compares the functional responsibilities of a product manager and a product owner. Approaches to structuring software development teams are considered. The responsibilities and tasks of the product manager and product owner are discussed. It is established that the responsibilities of the product manager differ significantly at different stages of product development. The classification of product managers on the basis of the degree of novelty of the version of the software product they are working on, the degree of involvement in the stages of product development, the degree of in- 
volvement in a particular stage of development of the startup is considered. It is found that the product manager as a member of the project team is responsible for making business decisions and developing product strategy, and the product owner is responsible for creating the value of the IT product. The product manager explores the competitive environment and target audience, and then works with teams of developers and marketers to bring existing solutions to market. The product manager concentrates his efforts on developing the product that will bring the greatest profit with minimal investment. The product manager is responsible for the vision and direction of product development in the long-term strategy of the company. The product owner manages the backlog, develops the product roadmap and to-do list in the project, and presents the product to developers and other stakeholders. The product owner interacts with the product manager, project team, and product users through the ability to develop, maintain, and ensure software quality. The product owner is responsible for creating product value of the company in the short-term strategy. In part, the responsibilities of the product manager and the product owner intersect. Delegating the role of product manager and product owner to one person can lead to a loss of strategic vision of the IT product's goals or excessive immersion in the software development process.

Keywords: agile, Scrum, methodology, product, manager, owner, responsibilities, skills.

Стаття надійшла 22.02.2021

Прийнято 12.03.2021 